\title{
A comparative Study of Immunohistochemical Expression of Tumor Necrosis Factor-Alpha, Interleukin-6and Vascular Endothelial Growth Factor in Giant Cell Granuloma of the Jaws and Giant Cell Tumor of Long Bones
}

\author{
Saba F. Naji \\ B.D.S. - Master Student. \\ Wasan H. Younis \\ Ph.D. - Professor, Department of Oral Diagnosis, College of Dentistry, University of Baghdad \\ Bashar H. Abdullah \\ Ph.D.. - Professor, Department of Oral Diagnosis, College of Dentistry, University of Baghdad
}

\begin{abstract}
Background: Central giant cell granuloma (CGCG) and peripheral giant cell granuloma(PGCG) are pathological conditions of the jaws that share the same microscopic features, but differ clinically in terms of their behavior. While the giant cell tumor (GCT) of long bones is a rare benign neoplasm, tend to affect femur and tubular bone, characterized by local aggressiveness, high recurrence rates and metastasis to the lung.

Objectives: To evaluate, compare and correlate the expression of TNF- $\alpha$, IL- 6 and VEGF in peripheral and central giant cell granuloma of the jaw and giant cell tumor of long bones.

Methods: A total of 60 retrospective formalin- fixed, paraffine-embeded specimens of giant cell lesions of the jaws and long bones, where included in this study. An immunohistochemical staining with TNF- $\alpha$, IL- 6 and VEGF monoclonal antibodies were performed.

Results: TNF- $\alpha$, IL-6 and VEGF were expressedin all lesions. The PGCG comparedto the CGCG and GCT showed significantly increased expression of TNF- $\alpha$ and decreased expression of VEGF by the stromal cells..GCT showed increased expression of VEGF by M NGCs and stromal cells. There is a non significant difference between CGCG and GCT regarding the expression of all three cytokines.

Conclusions: The present study confirmed the usefulness TNF- $\alpha, \mathrm{IL}-6$ and VEGF in evaluating osteoclastogenesis. The results of this study proved that the biological activity of TNF- $\alpha$, IL- 6 and VEGF was comparable between the central giant cell granuloma and giant cell tumors, supporting the observations that these two lesions are the same entity and have the same biological behavior. KEY WORD
\end{abstract}

central giant cell granuloma, Peripheral giant cell granuloma, Giant cell tumor

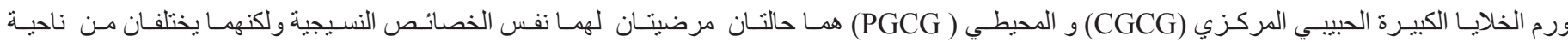

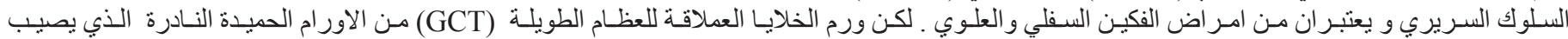

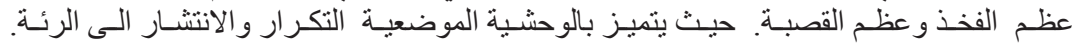

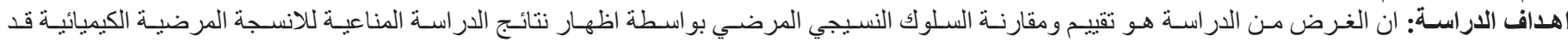

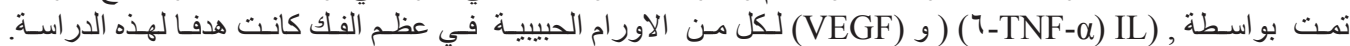

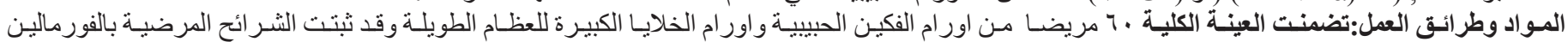

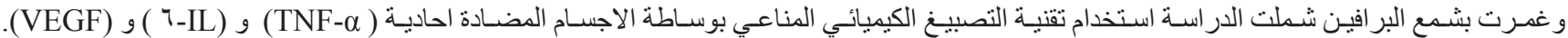

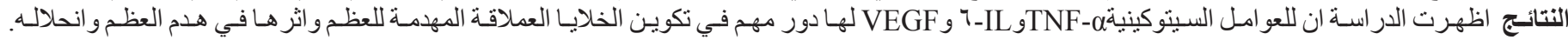

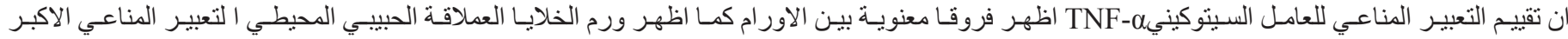

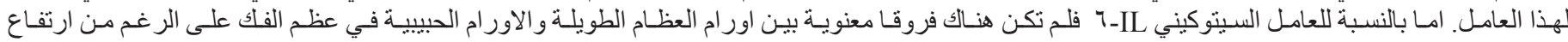

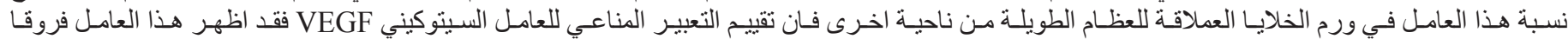

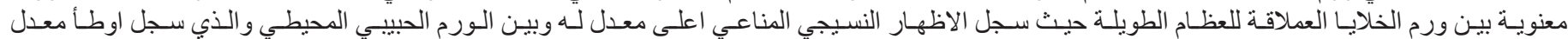

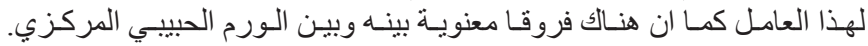

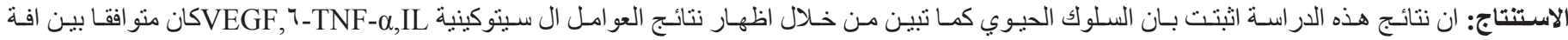

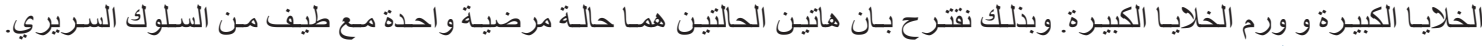

الكلمات الرئيسة الكئة

الورم الحبيبي المركزي-الورم الحبيبي المحيطي-ورم العظام الطويلة 


\section{INTRODUCTION}

Many lesions of the jaws contain giant cells, they include peripheral giant cell granuloma, central giant cell granuloma, aneurysmal bone cyst, brown tumor of hyperparathyroidism and early stage of cherubism ${ }^{(1)}$

Giant cell granuloma which is a benign bone lesion that occurs mainly in the jaws, not tumor but like condition. Giant cell granuloma presented either as central or peripheral giant cell granuloma. They are of unknown origin located more frequently in the mandible than maxilla, occurring in the 2 nd and 3rd decades of life. Females are more frequently affected than males ${ }^{(2,3)}$. PGCG is a reactive exophytic lesion occurring on the gingival and the alveolar ridge originating from the periosteum or periodontal membrane ${ }^{(4)}$.

On the other hand giant cell tumor is a low grade locally aggressive neoplasm that develops within the long bone of young adults of 20-40 years of age. It constitutes about $4-5 \%$ of all bone tumors and about $18 \%$ of all benign bone tumors. It is generally considered a true neoplastic condition with well defined clinical, radiological and histopathological features ${ }^{(5)}$. It apparently arises from the mesenchymal cells of the connective tissue frame work. These cells differentiate into fibroblast-like stromal components and multinucleated cells of osteoclastic type ${ }^{(6,7)}$.

The histological features of each of these lesions are markedly similar although they vary substantially in their clinical behavior. However, sometimes they switch from relatively indolent growth pattern to become rapidly enlarging and destructive one with recurrence tendency. Controversy still exists whether the CGCG that occurs in the jaws is a true neoplasm and identical to those occurs in the long bones ${ }^{(3,8)}$.

A diverse array of inflammatory cytokines and chemokines promote the formation of multinucleated osteoclast cells. Osteoclasts are typically present in large numbers in GCT of bone, suggesting that these tumors may contain cell expressing factors that stimulate osteoclast precursor recruitment and differentiation ${ }^{(9)}$. Osteolysis is a common complication of tumors that arise in, or metastasize to, bone. Considerable progress has been made toward an understanding of the mechanisms responsible for physiological osteoclastogenesis.

A large number of growth factors, hormones and cytokines have been identified that can exert direct and indirect stimulatory and antagonistic effects on the development of osteoclasts from hematopoietic precursors.

\section{MATERIAL AND METHODS}

In thisstudy, files of patients with a definite diagnosis of PGCG and CGCG from the Department of Oral and Maxillofacial Pathology, College of Dentistry, University of Baghdad were revised. The cases of GCT from Ghazi - Al-Harriri hospital, the diagnosis in each case having been made on the basis of clinical, radiologic and histologic findings. Formalin- fixed and paraffin-embedded- tissue samples of all the cases were retrieved. All specimens were obtained from surgical excision of the lesions and had been fixed in $10 \%$ buffered formalin. The (H\&E) stained slides for all cases were reviewed by two histopathologists. The positive control slides were prepared from blocks of patients having tissue known to contain the target antigen against which the primary antibodies used in this study respectively. Positive tissue controls included radicular cyst for TNF- $\alpha$, cervical squamous cell carcinoma for IL-6 and human kidney for VEGF. For negative controls slides the antibody was omitted. In eachsection, eight high-power fields were randomly selected, with a 40X magnification restricted to relatively cellular areas containing MNGC, were randomly chosen in each section to obtain the maximum number of highpower fields common to all samples and to allow direct comparisons among them. The MNGC and stromal cells with a clearly defined immunostaining compared with the positive control cells were counted, and the percentage of positively stained cells (PP) of the M NGCs and stromal spindle-shaped cells was assessed in each field by two observersas: 0 ( $<10 \%$ stained cells), $1(\geq 10 \%), 2(\geq 25 \%), 3(\geq 50 \%)$, and4 $(\geq 75 \%)$ this is for TNF- $\alpha$ and IL- $6^{(10,11)}$ while for VEGF; 0 , no stained cells; $1, £ 25 \%$ stained cells; $2,>25 \%$ and $<50 \%$ stained cells; $3,>50 \%$ and $<75 \%$ stained cells; and $4,>75 \%$ stained cells ${ }^{(12)}$.Statistical analysis was performed by SPSS version 19 statistical package. Because the data were conformed to abnormal distributions, the non-parametric Mannhitneywasused. The differences were considered as statistically significant at level $p=0.05$

\section{RESULTS}

All tumors showed similar histological features exhibiting a great number of MNGCs surrounded by cell populations with oval to spindle cell morphology in a loose fibrillar connective tissue stroma with many small blood vessels. TNF- $\alpha$ Fig(1) (A,B,C), Fig (2) (A,B,C). IL-6 Fig (3) (A,B,C) and VEGF Fig(4)(A,B,C) were detected in all cases of PGCGs, CGCGs and GCT. The MNGCs expressed IL-6 and 
VEGF in all cases of PGCGs, CGCGs and GCT as cytoplasmic immunostaining while for TNF- $\alpha$ as nuclear and cytoplasmic immunistaining Fig(1) $(\mathrm{A}, \mathrm{B}, \mathrm{C})$ and cytoplasmic immunostaining as in $\operatorname{Fig}(2)$ $(\mathrm{A}, \mathrm{B}, \mathrm{C})$. There was a statistically highly significant difference between PGCG, CGCG\&GCT considering the expression ofTNF- $\alpha$ by MNGCs \& stromal cells as illustrated in Table $(1,2)$, in contrast to IL-6 which show anon significant difference between CGCG, PGCG \& GCT as represented in Table (3). VEGF shows a highly significant difference between CGCG \& PGCG \& on the other hand between PGCG\&GCT by stromal cells as illustrated in Table(4,5). Considering the statistical correlation between the expression of the three markers in CGCG, elucidated that there is a direct moderate relation between the expression

Table 1: Comparison for TNF- $\alpha$ expression among studied giant cells lesion types according to cell types

\begin{tabular}{|c|c|c|c|c|c|c|c|c|c|c|c|}
\hline \multirow{2}{*}{$\begin{array}{c}\text { Mark- } \\
\text { er }\end{array}$} & \multirow{2}{*}{$\begin{array}{l}\text { Cell } \\
\text { Type }\end{array}$} & \multirow{2}{*}{$\begin{array}{c}\text { Lesion } \\
\text { Type }\end{array}$} & \multicolumn{6}{|c|}{ Descriptive statistics } & \multicolumn{3}{|c|}{ Lesion types' comparison } \\
\hline & & & $N$ & Mean \% & S.D. & S.E. & Min. & $\operatorname{Max}$. & $\begin{array}{l}\text { Kruskal } \\
\text { Wallis test }\end{array}$ & P-value & Sig. \\
\hline \multirow{6}{*}{$\mathrm{TNF} \alpha$} & \multirow{3}{*}{ MNGC } & C.G.C.G & 20 & 72.2 & 26.83 & 6.00 & 22 & 100 & \multirow{3}{*}{6.67} & \multirow{3}{*}{0.036} & \multirow{3}{*}{$\mathrm{S}$} \\
\hline & & P.G.C.G & 20 & 80.3 & 17.40 & 3.89 & 38 & 100 & & & \\
\hline & & G.C.T & 20 & 59.5 & 27.46 & 6.14 & 15 & 99 & & & \\
\hline & \multirow{3}{*}{ S-cell } & C.G.C.G & 20 & 63.05 & 25.42 & 5.68 & 18 & 98 & \multirow{3}{*}{13.87} & \multirow{3}{*}{0.001} & \multirow{3}{*}{$\mathrm{HS}$} \\
\hline & & P.G.C.G & 20 & 84.3 & 16.86 & 3.77 & 45 & 99 & & & \\
\hline & & G.C.T & 20 & 60.85 & 22.30 & 4.99 & 17 & 92 & & & \\
\hline
\end{tabular}

Table 2: Mann-Whitney U test

\begin{tabular}{|c|c|c|c|c|c|c|}
\hline Marker & Cell Type & \multicolumn{2}{|c|}{ Lesion type } & Mann-Whitney $U$ test & P-value & Sig. \\
\hline \multirow{6}{*}{$\mathrm{TNF} \alpha$} & \multirow{3}{*}{ MNGC } & \multirow{2}{*}{ C.G.C.G } & P.G.C.G & 177.5 & 0.54 & NS \\
\hline & & & G.C.T & 140 & 0.104 & NS \\
\hline & & P.G.C.G & G.C.T & 102.5 & 0.008 & HS \\
\hline & \multirow{3}{*}{ S-cell } & \multirow{2}{*}{ C.G.C.G } & P.G.C.G & 98.5 & 0.006 & HS \\
\hline & & & G.C.T & 188.5 & 0.76 & NS \\
\hline & & P.G.C.G & G.C.T & 66.5 & 0.000 & HS \\
\hline
\end{tabular}

of VEGF in stromal cells $(\mathrm{r}=0.50)$, with significant relation $(\mathrm{p}=0.03)$ in relation to TNF- $\alpha$ expression as shown in Table(6). Regarding spearman's test correlation in PGCG demonsetrates that the VEGF in stromal cells has an indirect moderate relation with TNF- $\alpha(\mathrm{r}=-0.47)$, significant relation $(\mathrm{p}=0.04)$. Similarly, VEGF expression in stromal cells has an inverse moderate relation to IL-6 expression ( $\mathrm{r}=$ $0.59) \&(p=0.01)$ as illustrated in Table (7). While in GCT, statistical analysis revealed that, there is a direct significant correlation in expression of TNF- $\alpha$ by stromal cells with MNGCs $(\mathrm{r}=0.52)$, and $(\mathrm{p}=0.02)$. On the other hand IL- 6 and TNF- $\alpha$ expression by the MNGCs demonstrated a direct significant correlation to $(r=0.48)$, and $(p=0.03)$ as shown in Table (8). 
Table 3: Descriptive statistics for IL-6 expression among giant cell lesions

\begin{tabular}{|c|c|c|c|c|c|c|c|c|c|c|c|}
\hline \multirow{2}{*}{ Marker } & \multirow{2}{*}{$\begin{array}{l}\text { Cell } \\
\text { Type }\end{array}$} & \multirow{2}{*}{$\begin{array}{c}\text { Lesion } \\
\text { Type }\end{array}$} & \multicolumn{6}{|c|}{ Descriptive statistics } & \multicolumn{3}{|c|}{ Lesion types' comparison } \\
\hline & & & $N$ & Mean\% & S.D. & S.E. & Min. & Max. & $\begin{array}{c}\text { Kruskal } \\
\text { Wallis test }\end{array}$ & P-value & Sig. \\
\hline \multirow{6}{*}{ IL-6 } & \multirow{3}{*}{ MNGC } & C.G.C.G & 20 & 71.8 & 15.60 & 3.49 & 50 & 100 & \multirow{3}{*}{2.78} & \multirow{3}{*}{0.25} & \multirow{3}{*}{ NS } \\
\hline & & P.G.C.G & 20 & 68.7 & 24.57 & 5.49 & 10 & 98 & & & \\
\hline & & G.C.T & 20 & 79.3 & 14.70 & 3.29 & 44 & 100 & & & \\
\hline & \multirow{3}{*}{ S-cell } & C.G.C.G & 20 & 59.25 & 17.90 & 4.00 & 20 & 90 & \multirow{3}{*}{1.39} & \multirow{3}{*}{0.49} & \multirow{3}{*}{ NS } \\
\hline & & P.G.C.G & 20 & 60.55 & 15.87 & 3.55 & 20 & 90 & & & \\
\hline & & G.C.T & 20 & 65.15 & 25.68 & 5.74 & 15 & 99 & & & \\
\hline
\end{tabular}

Table 4: Descriptive statistics for VEGF expression among giant cell lesions

\begin{tabular}{|c|c|c|c|c|c|c|c|c|c|c|c|}
\hline \multirow{2}{*}{ Marker } & \multirow{2}{*}{$\begin{array}{l}\text { Cell } \\
\text { Type }\end{array}$} & \multirow{2}{*}{$\begin{array}{c}\text { Lesion } \\
\text { Type }\end{array}$} & \multicolumn{6}{|c|}{ Descriptive statistics } & \multicolumn{3}{|c|}{ Lesion types' comparison } \\
\hline & & & $\boldsymbol{N}$ & Mean\% & S.D. & S.E. & Min. & Max. & $\begin{array}{l}\text { Kruskal } \\
\text { Wallis test }\end{array}$ & $\begin{array}{c}\text { P-val- } \\
\text { ue }\end{array}$ & Sig. \\
\hline \multirow{6}{*}{ VEGF } & \multirow{3}{*}{ MNGC } & C.G.C.G & 20 & 72.8 & 23.02 & 5.15 & 18 & 99 & \multirow{3}{*}{0.79} & \multirow{3}{*}{0.68} & \multirow{3}{*}{ NS } \\
\hline & & P.G.C.G & 20 & 76 & 20.15 & 4.51 & 27 & 94 & & & \\
\hline & & G.C.T & 20 & 80.1 & 16.55 & 3.70 & 22 & 94 & & & \\
\hline & \multirow{3}{*}{ S-cell } & C.G.C.G & 20 & 72.05 & 17.50 & 3.91 & 43 & 99 & \multirow{3}{*}{15.19} & \multirow{3}{*}{0.001} & \multirow{3}{*}{ HS } \\
\hline & & P.G.C.G & 20 & 49.1 & 16.11 & 3.60 & 27 & 78 & & & \\
\hline & & G.C.T & 20 & 70.85 & 18.92 & 4.23 & 24 & 93 & & & \\
\hline
\end{tabular}

Table 5: Mann-Whitney U test

\begin{tabular}{|c|c|c|c|c|c|c|}
\hline Marker & Cell Type & \multicolumn{2}{|c|}{ Lesion type } & Mann-Whitney $U$ test & P-value & Sig. \\
\hline \multirow{3}{*}{ VEGF } & \multirow{3}{*}{ S-cell } & C.G.C.G & P.G.C.G & 77.5 & 0.001 & HS \\
\hline & & & G.C.T & 191 & 0.81 & NS \\
\hline & & P.G.C.G & G.C.T & 74.5 & 0.001 & HS \\
\hline
\end{tabular}


Table 6: Correlation among the markers in central giant cell granuloma.

\begin{tabular}{|c|c|c|c|c|c|c|c|}
\hline \multirow{2}{*}{ Markers } & \multirow{2}{*}{ Cells } & & \multirow{2}{*}{$\frac{T N f}{S}$} & \multicolumn{2}{|c|}{ IL-6 } & \multicolumn{2}{|c|}{ VEGF } \\
\hline & & & & $M$ & $S$ & $M$ & $S$ \\
\hline \multirow{4}{*}{$\mathrm{TNF} \alpha$} & \multirow{2}{*}{ MNGC } & $\mathrm{r}$ & 0.42 & 0.16 & -0.01 & 0.19 & -0.37 \\
\hline & & $\mathrm{p}$ & 0.07 & 0.49 & 0.97 & 0.43 & 0.11 \\
\hline & \multirow{2}{*}{$\mathrm{S}$} & $\mathrm{r}$ & & 0.25 & 0.22 & 0.50 & -0.36 \\
\hline & & $\mathrm{p}$ & & 0.28 & 0.34 & $0.03(\mathrm{~S})$ & 0.12 \\
\hline \multirow{4}{*}{ IL-6 } & \multirow{2}{*}{ MNGC } & $\mathrm{r}$ & & & 0.31 & 0.07 & -0.16 \\
\hline & & $\mathrm{p}$ & & & 0.19 & 0.77 & 0.49 \\
\hline & \multirow{2}{*}{$\mathrm{S}$} & $\mathrm{r}$ & & & & 0.05 & -0.15 \\
\hline & & $\mathrm{p}$ & & & & 0.84 & 0.53 \\
\hline \multirow{2}{*}{ VEGF } & \multirow{2}{*}{ MNGC } & $\mathrm{r}$ & & & & & 0.31 \\
\hline & & $\mathrm{p}$ & & & & & 0.18 \\
\hline
\end{tabular}

Table 7: Correlation among the studied markers in periphral giant cell granuloma

\begin{tabular}{|c|c|c|c|c|c|c|c|}
\hline \multirow{2}{*}{ Markers } & \multirow{2}{*}{ Cells } & & \multirow{2}{*}{$\frac{T N S}{S}$} & \multicolumn{2}{|c|}{$I L-6$} & \multicolumn{2}{|c|}{ VEGF } \\
\hline & & & & $M$ & $S$ & $M$ & $S$ \\
\hline \multirow{4}{*}{$\mathrm{TNF} \alpha$} & \multirow{2}{*}{ MNGC } & $\mathrm{R}$ & 0.27 & 0.40 & -0.05 & 0.22 & 0.10 \\
\hline & & $\mathrm{P}$ & 0.25 & 0.08 & 0.84 & 0.34 & 0.68 \\
\hline & \multirow{2}{*}{ S } & $\mathrm{R}$ & & 0.18 & 0.29 & 0.02 & -0.47 \\
\hline & & $\mathrm{p}$ & & 0.45 & 0.21 & 0.94 & $0.04(\mathrm{~S})$ \\
\hline \multirow{4}{*}{ 'IL-6 } & \multirow{2}{*}{ MNGC } & $\mathrm{r}$ & & & 0.18 & 0.21 & -0.10 \\
\hline & & $\mathrm{p}$ & & & 0.46 & 0.37 & 0.67 \\
\hline & \multirow{2}{*}{$\mathrm{S}$} & $\mathrm{r}$ & & & & -0.11 & -0.59 \\
\hline & & $\mathrm{p}$ & & & & 0.65 & $0.01(\mathrm{HS})$ \\
\hline \multirow{2}{*}{ VEGF } & \multirow{2}{*}{ MNGC } & $\mathrm{r}$ & & & & & 0.27 \\
\hline & & $\mathrm{p}$ & & & & & 0.26 \\
\hline
\end{tabular}

Table 8: Correlation among the markers in giant cell tumor.

\begin{tabular}{|c|c|c|c|c|c|c|c|}
\hline \multirow{2}{*}{ Markers } & \multirow{2}{*}{ Cells } & & \multirow{2}{*}{$\begin{array}{c}T N f \\
S\end{array}$} & \multicolumn{2}{|c|}{$I L-6$} & \multicolumn{2}{|c|}{ VEGF } \\
\hline & & & & $M$ & $S$ & $M$ & $S$ \\
\hline \multirow{4}{*}{$\mathrm{TNF} \alpha$} & \multirow{2}{*}{ MNGC } & $\mathrm{R}$ & 0.52 & 0.48 & 0.20 & -0.02 & 0.00 \\
\hline & & $\mathrm{P}$ & $0.02(\mathrm{~S})$ & $0.03(\mathrm{~S})$ & 0.41 & 0.93 & 0.98 \\
\hline & \multirow{2}{*}{$\mathrm{S}$} & $\mathrm{R}$ & & 0.38 & 0.30 & -0.04 & -0.13 \\
\hline & & $\mathrm{P}$ & & 0.10 & 0.20 & 0.85 & 0.59 \\
\hline \multirow{4}{*}{ IL-6 } & \multirow{2}{*}{ MNGC } & $\mathrm{R}$ & & & 0.43 & 0.13 & -0.22 \\
\hline & & $\mathrm{P}$ & & & 0.06 & 0.58 & 0.36 \\
\hline & \multirow{2}{*}{$\mathrm{S}$} & $\mathrm{R}$ & & & & -0.34 & -0.03 \\
\hline & & $\mathrm{P}$ & & & & 0.14 & 0.89 \\
\hline \multirow{2}{*}{ VEGF } & \multirow{2}{*}{ MNGC } & $\mathrm{R}$ & & & & & 0.39 \\
\hline & & $\mathrm{P}$ & & & & & 0.09 \\
\hline
\end{tabular}




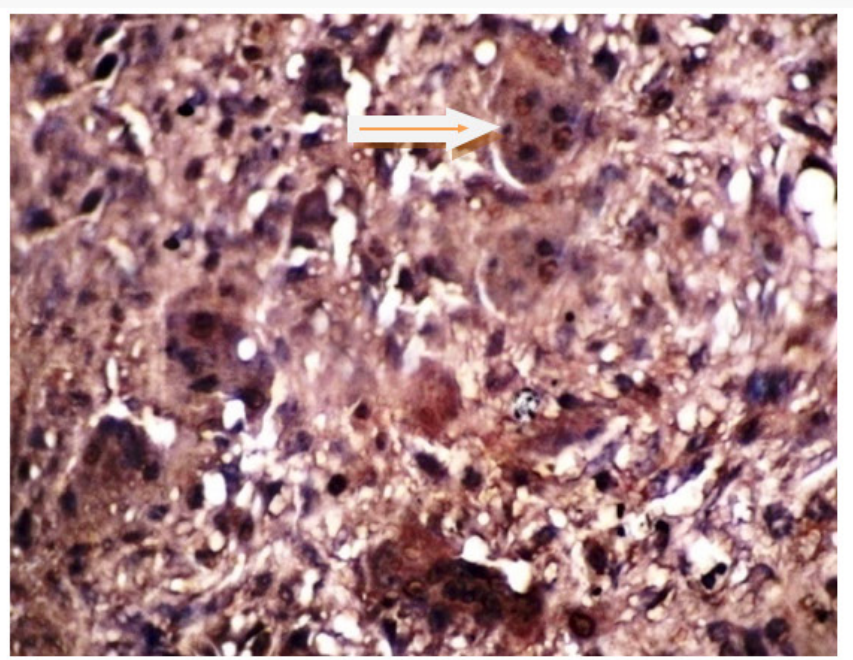

(A)

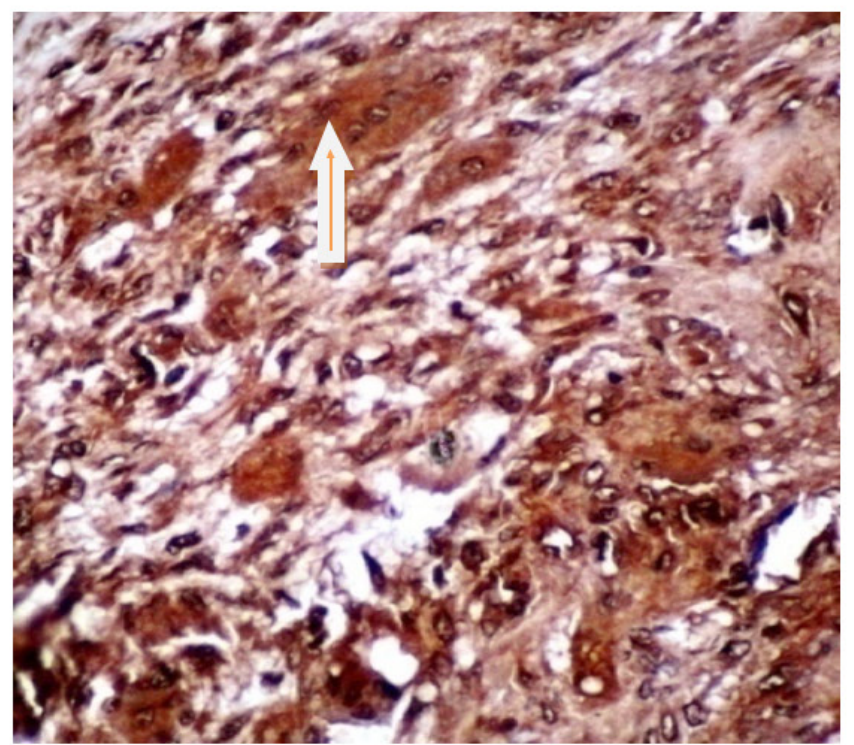

(B)

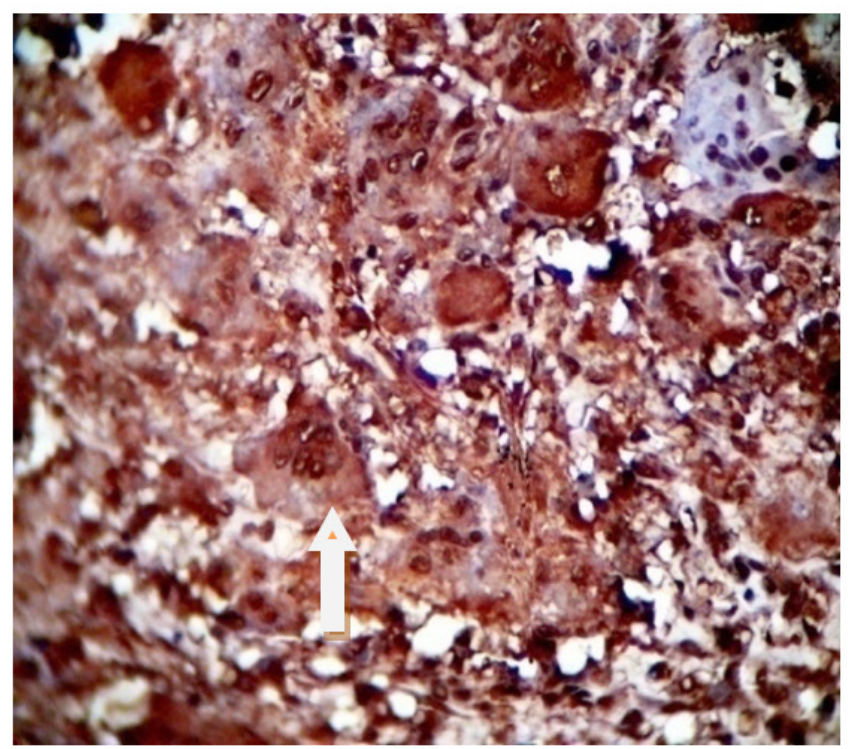

(C)

Figure 1: positive nuclear and cytoplasmic expression of TNF- $\alpha$ (A) Central giant cell granulona 400X, (B) Peripheral giant cell granulona 400X, (C) Giant cell tumor 400X

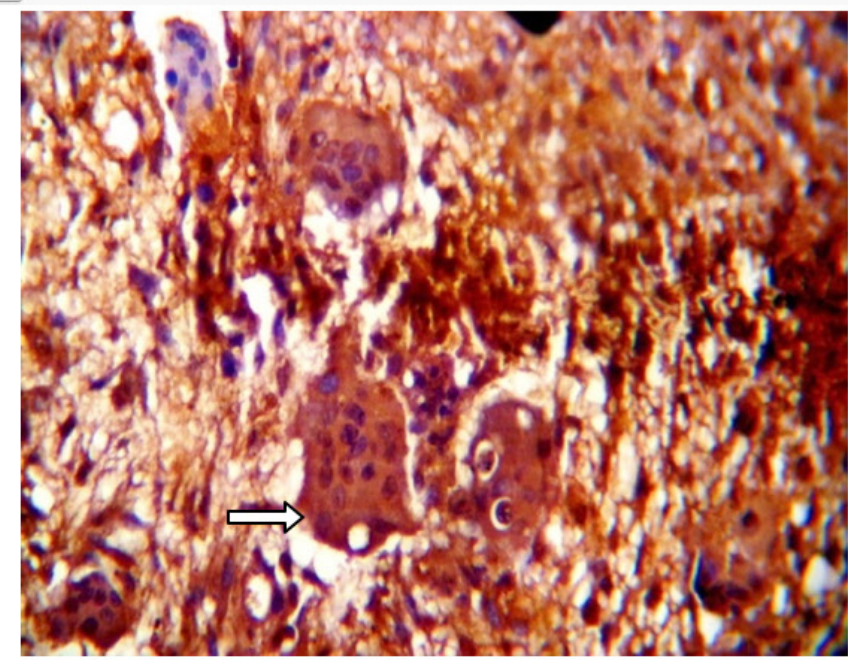

(A)

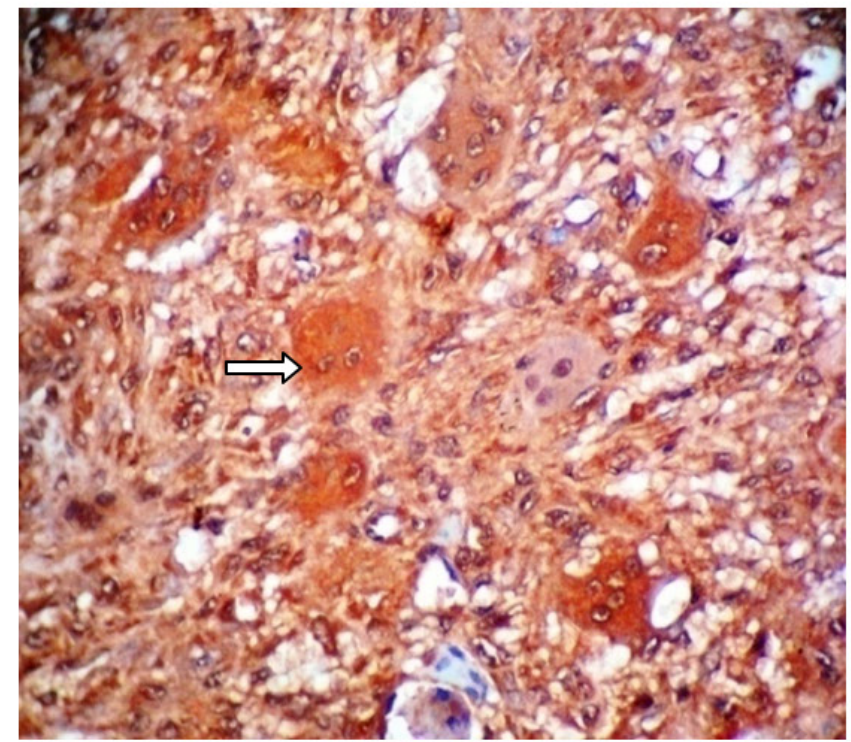

(B)

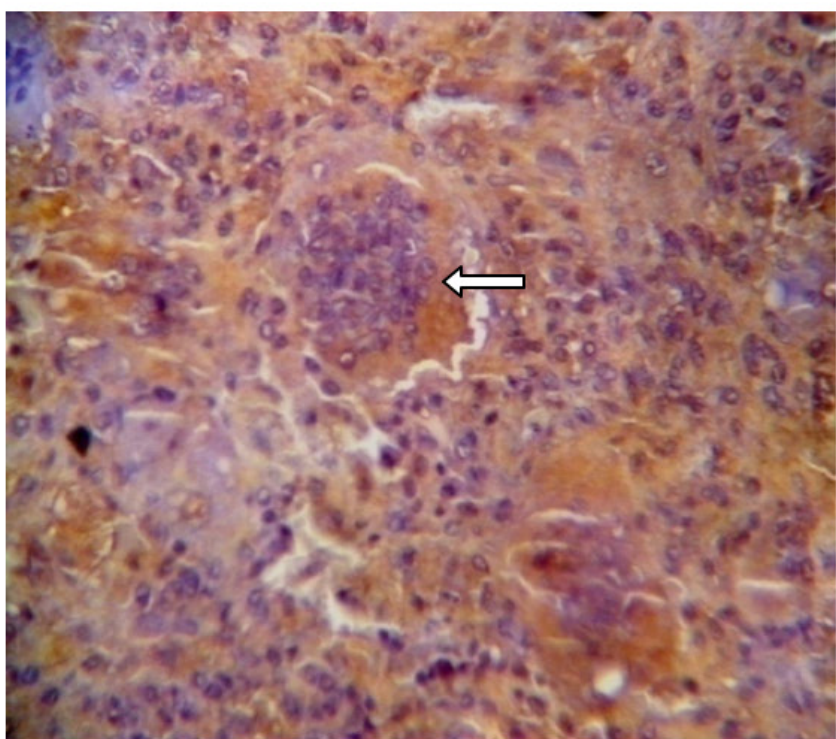

(C)

Figure 2: cytoplasmic expression of TNF- $\alpha$ positive (A) Central giant cell granulona 400X, (B) Peripheral giant cell granulona 400X, (C) Giant cell tumor 400X 


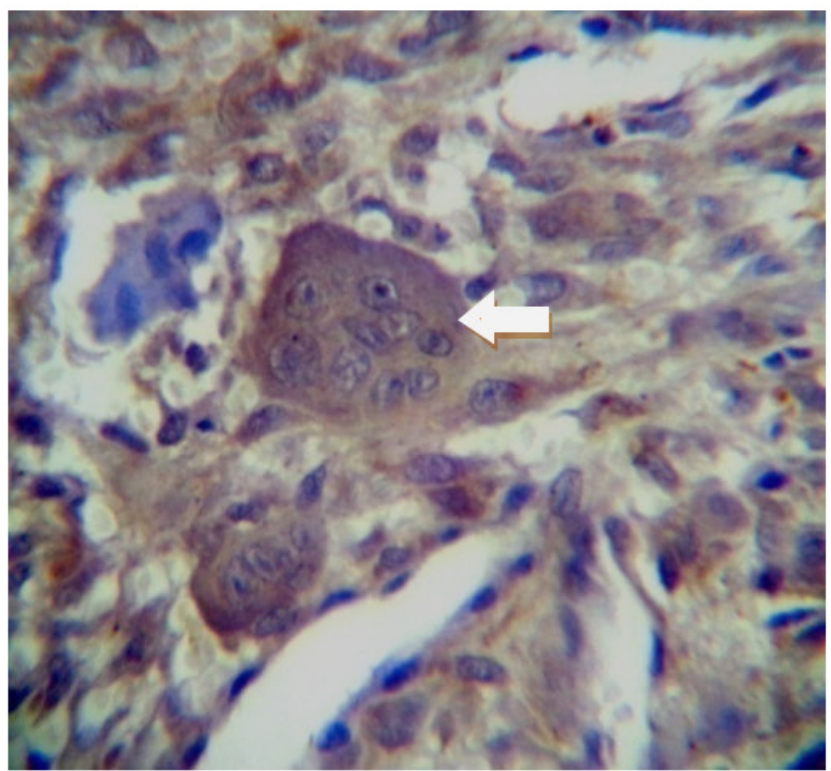

(A)

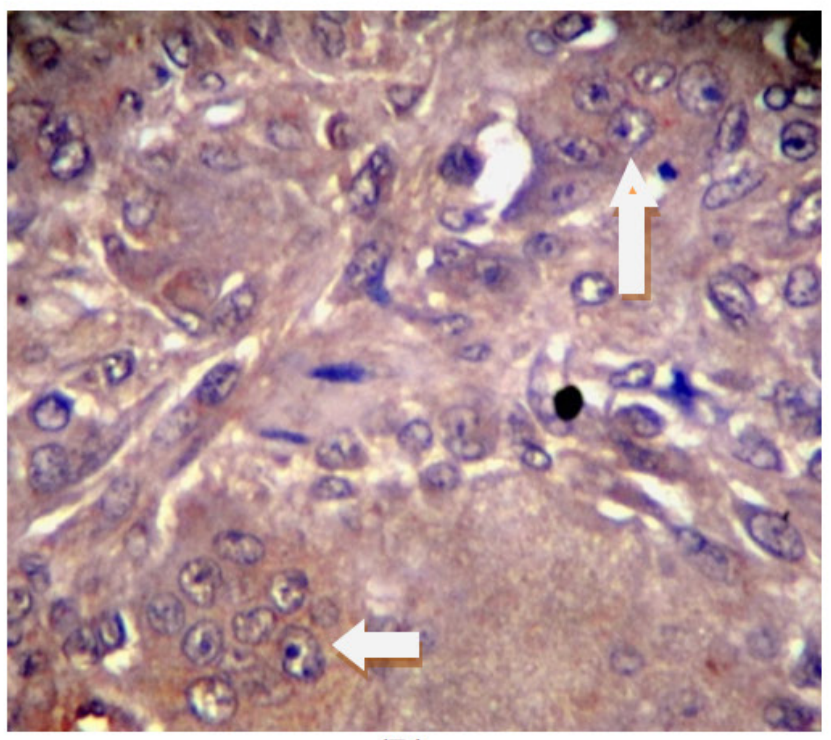

(B)

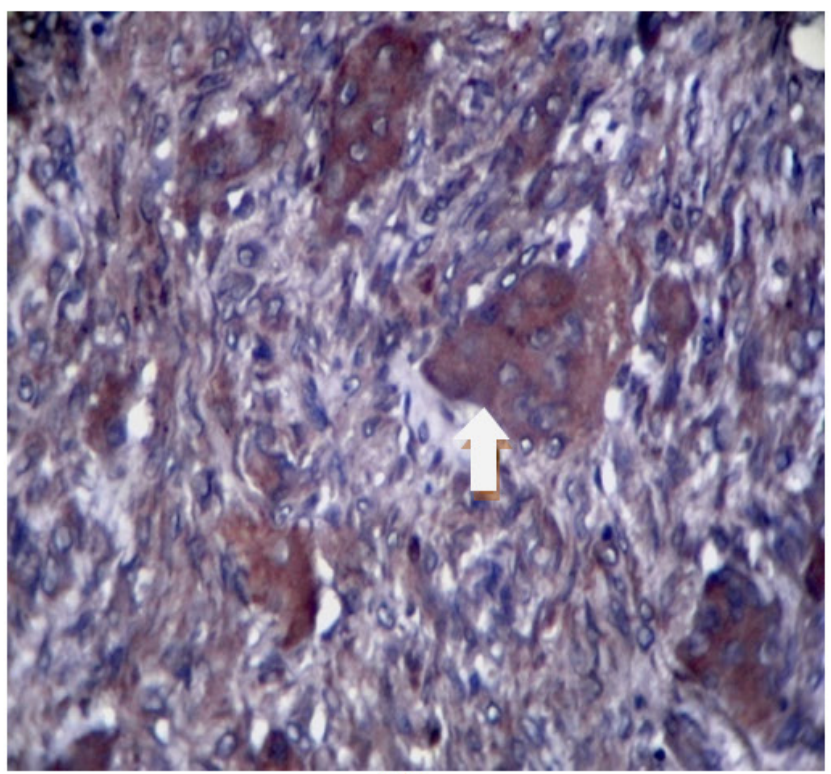

(C)

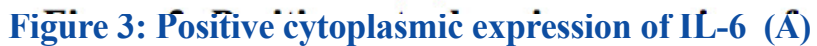

Central giant cell granulona 400X, (B) Peripheral giant cell granulona 400X, (C) Giant cell tumor 400X

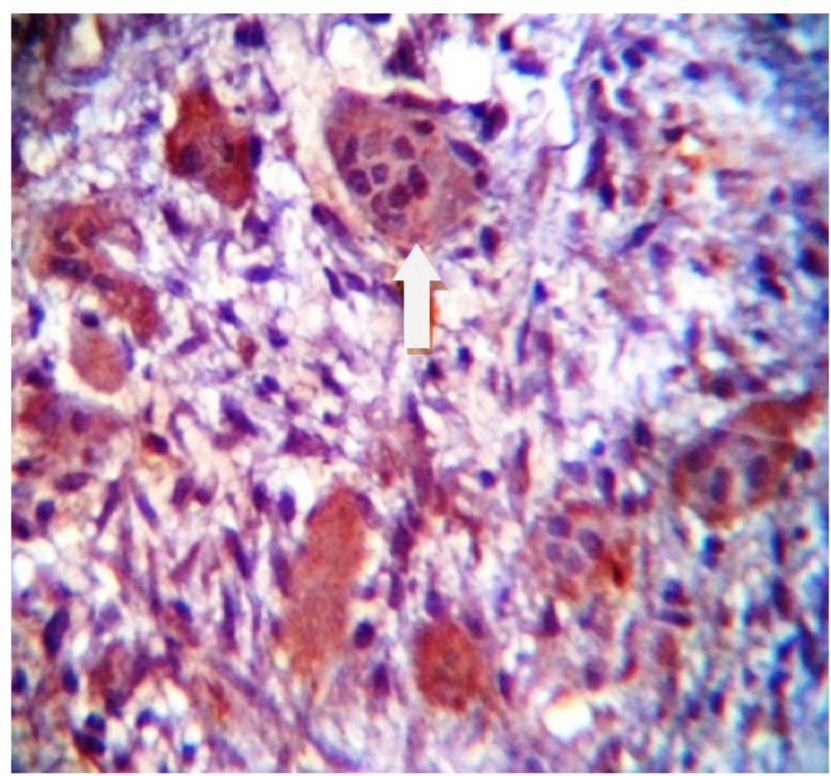

(A)

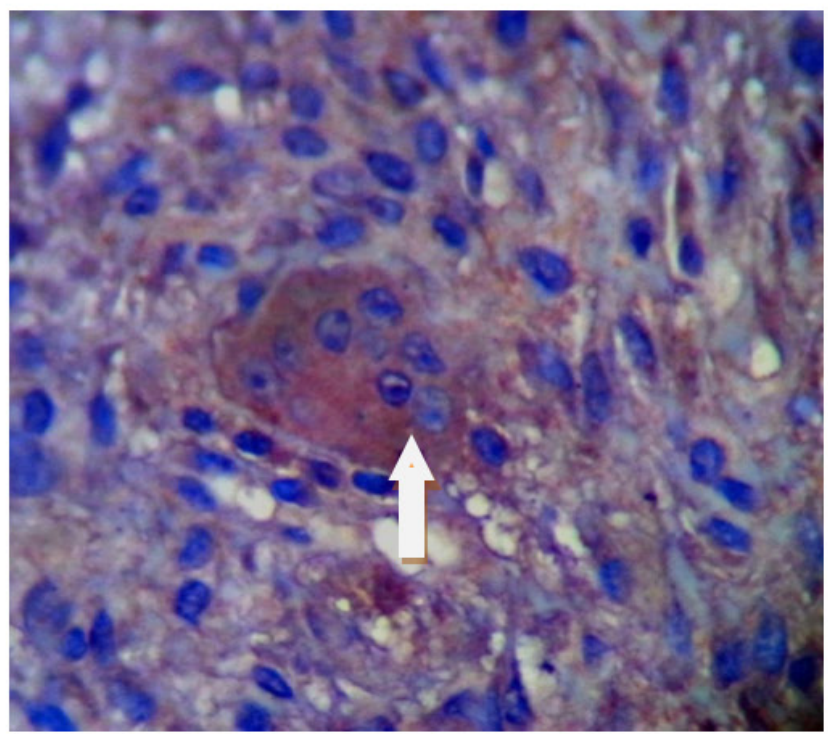

(B)

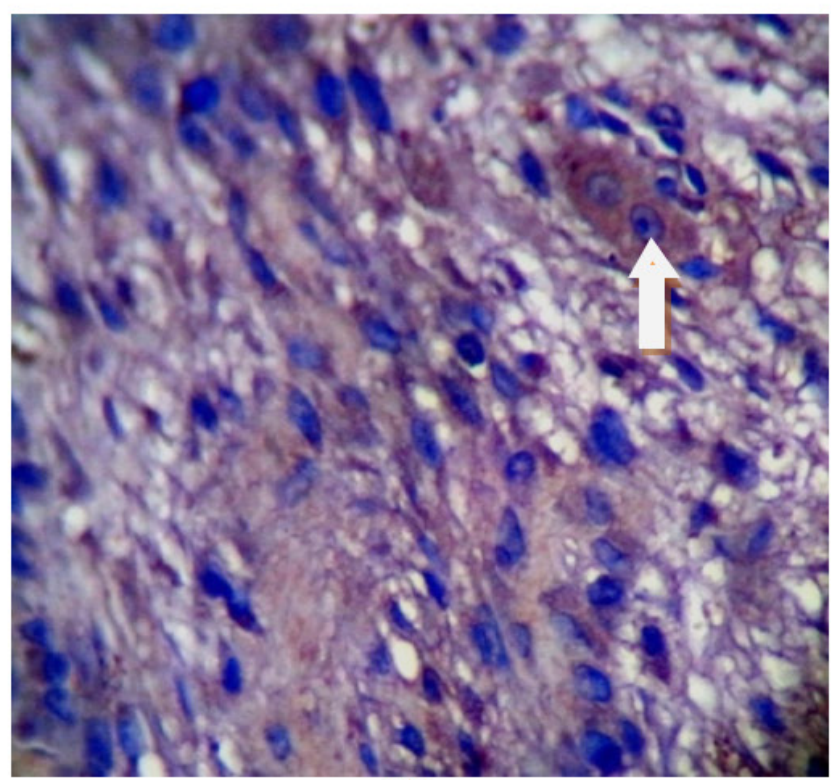

(C)

Figure 4: Positive cytoplasmic expression of $\operatorname{VEGF}^{\text {(A) }}$ Cèntral giant cell granulona 400X, (B) Peripheral giant cell granulona 400X, (C) Giant cell tumor 400X 


\section{DISCUSSION}

Some argument is still found whether the GCGs of the jaws and the GCT s of long bones are really a single pathologic process is an unanswered question.. TNF- $\alpha$ mostly expressed as cytoplasmic , this in agreement with ${ }^{(11)}$. Nuclear and cytoplasmic expression of TNF- $\alpha$ in the present study concise with (13), who showed increased transcription of nuclear factor of activated $\mathrm{T}$ cells (NAFT) ,"a master of transcription in terminal differentiation of osteoclasts" in the nucleous of MNGCs under the influence of stimuli triggered by TNF- $\alpha$.In order to compare between the CGCG, PGCG and GCT considering the expression of TNF- $\alpha$ cytokine, the present study results found that, there is a highly significant difference between PGCG and GCT, also between PGCG and CGCG. This finding is confirmed by ${ }^{(14)}$, who demonstrate that the PGCG is the most lesion express TNF- $\alpha$. This high expression of TNF- $\alpha$ is coherent with the reactive nature of these lesions, in which local irritating factors that trigger an inflammatory response promote a greater release of cytokines such as TNF- $\alpha$, which may contribute more to angiogenesis rather than bone resorption ${ }^{(15)}$.

On the other hand, there is a non significant difference between CGCG and GCT regardingthe expression ofTNF- $\alpha$, this is supported by previous Iraqi study ${ }^{(16)}$ who showed that there is a non significant difference between CGCG and GCT. The comparison among these three lesions(CGCG,PGCG\&GCT), revealed a none significant differences regarding the expression of IL- 6 by MNGCs, this is supported by ${ }^{(11)}$ This result indicate that this cytokine play acritical role in growth process of these lesions ${ }^{(11,17)}$ and IL-6 plays a critical role in MNGCs formation and regulation of bone resorption by the same mechanism ${ }^{(18)}$. In order to compare between these lesions, the present results showed that there is a highly significant difference between CGCG and PGCG in VEGF expression by stromal cells, this concise with ${ }^{(19,14)}$, suggesting that high levels of VEGF- producing cells in a CGCG would be related to a more aggressive biological behavior. . On the other hand, PGCG may provoke the resorption of underlying cortical bone ${ }^{(20)}$, the intensity of this process is significantly lower when compared to that observed in CGCG. Several studies investigating the phenotype of MNGC in CGCL and PGCL have reported consistent immunoreactivity to the anti-CD68 antibody, suggesting that these cells belong to the macrophage lineage ${ }^{(21)}$. Also there is a highly significant difference between PGCG and GCT, this is supported by ${ }^{(19)}$. The elevated level of
VEGF may therefore co-relate with the extent of osteolytic destruction of the lesion, regardless of its primary pathology ${ }^{(22)}$.

On the other hand the non significant relation between CGCG and GCT revealed immunohistochemical similarities between CGCG of the jaws and GCT of long bones, supporting the observation that sometimes these lesions are indistinguishable ${ }^{(21)}$, as well as VEGF expression may provide some prognostic indication of biologically aggressive behavior and local disease recurrence in any osteolytic lesion affecting bone. There was a direct correlation between VEGF \&TNF- $\alpha$, in this study demonstrated in the stromal cells. TNF- $\alpha$ signaling appears to coordinate the expression of specific regulators of endothelial cell survival and metalloproteolytic enzymes ${ }^{(23)}$. Furthermore, MMP9 mediates the release of extracellular matrix-bound VEGF, increasing vascularization (24). A negative correlation between the expression of VEGF\&TNFalpha was recoreded in this study Within this context, the lower expression of VEGF in PGCL observed in the present study agrees with ${ }^{(15)}$ who found lower expression of VEGF in PGCL compared to CGCL. VEGF may therefore co-relate with the extent of osteolytic destruction of the lesion ${ }^{(25)}$. This finding, together with the discrete trend towards higher expression of TNF-alpha ${ }^{(26)}$. The present study results suggested that there is a direct correlation between the stromal cells \&MNGCs in relation to the expression of TNF-alpha. This is due to the fact that, an established mechanism by which TNF promotes inflammatory bone resorption is activation of osteoblasts and tissue stromal cells to express receptor activator of NF- $x \mathrm{~B}$ (RANK) ligand (RANKL) ${ }^{(27,28)}$. On the other hand there is a direct relation between the expression of IL- 6 and TNF- $\alpha$ in MNGCs. Proinflammatory cytokines, such as TNF- $\alpha$, induce IL- 6 production through the activation of the p38 MAPK which, in turn, enhances the activity of $\mathrm{NF}-\kappa \mathrm{B}{ }^{(29)}$.

\section{CONCLUSION}

TNF- $\alpha$ expression in multinucleated giant cells and stromal cells of all cases of CGCG, and GCT confirmed its role in osteoclastogenesis. Its highest expression in PGCG, reflected the reactive nature of these lesions to local irritating factors. IL- 6 plays a positive regulatory role in osteoclast with the highest expression was in the GCT. This cytokine might be involved in the growth process and osteoclastogenesis of central giant cell granuloma of the jaw bones and GCT of bone, whereas in PGCG, may contribute 
mainly in the mechanism of tumor growth, and occasionally of osteolysis. VEGF showed a significantly higher expression in GCT in comparison to giant cell granuloma of jaw bones emphasized the importance of VEGF in osteoclastogenesis in addition angiogenesis. While in PGCG significantly lower VEGF expression leading to less bone destruction and acting as angiogenic stimulator rather than osteoclastogenic

The similarities in immunohistochemical expression between CGCG and GCT of long bones with a non significant difference between them regarding the expression of TNF,IL-6 andVEGF, supporting the observations that these two lesions are the same entity and indistinguishable and have the same biological behavior.

\section{REFERENCES}

1. Neville, B.W ; Damm, D.D : Bouqout, J.E. Oral maxillo facial pathology. WB. Saunders Company. 2005:p550 .

2. Corso E De , M Politi, [...], and G Paludetti Advanced giant cell reparative granuloma of the mandible: radiological features and surgical treatment.Acta Otorhinolaryngol 2006(3):168-172.

3. Neville, B.W; Damm,D.D; Allen,C.M;Bouquot,J.E. Bone Pathology. n: Oral and Maxillofaci 1 Pathology 3rd ed. WB. Sanders, Philadeiphia. 2009 ;14: 507-629

4. Chaparro-Avendaño AV, Berini-AytésL, Gay-Escoda C. Peripheral giant cell granuloma. Areport offive cases and review ofthe literature. Med Oral Patol Oral Cir Bucal.2005; 10:53-7; 48-52

5. McGough RL, Rutledge J, Lewis VO,Lin PP andYasko AW. Impact severity of local recurrence in giant cell tumor of bone.Ciin Orthop Re at Res 2005;438:116-122

6. Werner M. Giant cell tumor of bone : morphological, biological and histogenetical aspects. In t orthop 2006;30489

7. Lanza A., Luigi Laino, [...], and Nicola Cirillo Clinical Practice: Giant Cell Tumour of the Jaw Mimicking Bone Malignancy on Three-Dimensional Computed Tomography (3D CT) Reconstruction. Open Dent .J. 2008,2:174-178.

8. Bilodeau E, Khalid Chowdhury and Bobby Collins A Case of Recurrent Multifocal Central Giant Cell Granulomas. Head\&neck pathol.2009;3(2):174-178

9. Sophie R, Larbi A, Geri M, Anne, G-M, Edwin, Xavie M..RANK(receptor activator nuclear factor kappa B)and RANK ligand are expressedin giant cell tumor of bone.Am J Clin Pathol.2002;117(2): 210-17

10. Tobón SI, Franco-González LM, Isaza-Guzmán DM, Floréz-Moreno GA, Bravo-Vásquez T, Castañeda-Peláez DA, et al. Immunohistochemical expression of RANK, GR alpha and CTR in central giant cell granuloma of the jaws. Oral Oncol.2005;41:480-8.

11. 11.Papanicolaou P, Chrysomali E, Stylogianni E, Donta C, Vlachodimitripoulos D Increased TNF- $\alpha$, IL-6 and decreased IL-1 $\beta$ immunohistochemical expression by the stromal spindle-shaped cells in the central giant cell granuloma of the jaws Med Oral Patol Oral Cir Bucal. 2012;17 (1): 56-62
12. Flo' rez-Moreno GA, Henao-Ruiz M, Santa-Sa' enz DM, Castan eda-Pela' ez DA, Tobo' n-Arroyave SI. Cytomorphometric and immunohistochemical comparison between central and peripheral giant cell lesions of the jaws. Oral Surg Oral Med Oral Pathol Oral Radiol Endod 2008; 105: 625-32.

13. Amaral FR, Brito JA, Perdigao PF, et al. NFATc1 and TNF alpha expression in giant cell lesions of the jaws. J Oral Pathol Med 2010; 39: 269-74.

14. De Matos FR,De Moraes M, Nonak CF, De Souza LB, Freitas RA.. Immunoexpression of TNF-a and TGF-b in central and peripheral giant cell lesions of the jaws J Oral Pathol Med 2012; 41:194-199

15. Matos FR, Nonaka CF, Miguel MC, Galvao HC, Souza LB, Freitas RA. Immunoexpression of MMP-9, VEGF, and vWF in central and peripheral giant cell lesions of the jaws. J Oral Pathol Med 2011; 40: 338-44.

16. Abdul Khafoor S. Histopathological and Immunohistochemical expression nf (RANK), (TNF) \& (ALP) markers in giant cell tumor of bone and central giant cell granuloma of the jaw. A master thesis, Oral Medecine, Department of Oral Diagnosis, University of Baghdad 2008.

17. Gamberi G, Benassi MS, Ragazzini P, Pazzaglia L, Ponticelli F, Ferrari C, et al.Proteasesandinterleukin-6 gene analysisin 92 giant cell tumorsofbone.Ann Oncol 2004; 15:498-503.

18. Dai JC, He P, Chen X, Greenfield EM. TNF alpha and PTH utilize distinct mechanismsto in-duce IL-6 and RANKL expression ithmarkedly different kinetics.Bone 2006;38:509-20.

19. Vered M, Buchner A, Dayan D. Giant cell granuloma of the jaw bones: a proliferative vascular lesion? Immunohistochemical study with vascular endothelial growth factor and basic fibroblastic growth factor. J Oral Pathol Med. 2006;35(10):613-9.

20. Souza PE, Mesquita RA, Gomez RS. Evaluation of p53, PCNA, Ki-67, MDM2 and AgNOR in oral peripheral and central giant cell lesions. Oral Dis. 2000; 6: 35-9

21. Araga o M do S, Piva MR, Nonaka CF, Freitas Rde A, de Souza LB, Pinto LP. Central giant cell granuloma of the jaws and giant cell tumor of long bones: an immunohistochemical comparative study. J Appl Oral Sci 2007; 15: 310-6.

22. Kumta SM, Huang L, Cheng YY, Chow LT, Lee KM, Zheng MH. Expression of VEGF and MMP-9 in giant cell tumor of bone and other osteolytic lesions. Life Sci 2003; 73: 1427-1436.

23. Lehmann W.,' C.M. Edgar, K. Wang, T-J. Cho, G.L. Barnes ${ }^{\text {a }}$, S. Kakar, D.T. Graves ${ }^{d}$ J.M. Rueger, L.C. Gerstenfeld T.A. Einhorn ${ }^{\text {a, }}$ Tumor necrosis factor alpha (TNF- $\alpha$ ) coordinately regulates the expression of specific matrix metalloproteinases (MMPS) and angiogenic factors during fracture healing Bone 2005; 36, (2): 300-310

24. Rundhaug JE. Matrix metalloproteinases and angiogenesis. J Cell Mol Med 2005; 9: 267-85

25. Engsig MT, Chen QJ, Vu TH, Pedersen AC, Therkidsen B, Lund LR, Henriksen K, Lenhard T, Foged NT, Werb Z \& Delaissé JM. Matrix metalloproteinase 9 and vascular endothelial growth factor are essential for osteoclast recruitment into developing long bones. J Cell Biol 2000; 151: 879-889

26. Parameswaran N, Patial S. Tumor necrosis factor-alpha signaling in macrophages. Crit Rev Eukaryot Gene Expr 2010; 20: 87-103 
27. Kobayashi, K, Takahashi, N, JIMI, E, UDAGAWA, N, TAKAMI, M, KOTAKE, S, NAKAGAWA, N et al. Tumor necrosis factor alpha stimulates osteoclast differentiation by a mechanism independent of the ODF/RANKL-RANK interaction. The Journal of Experimental Medicine 2000; 191; p. 275-286.

28. Lam, J., S. Takeshita, J.E. Barker, O. Kanagawa, F.P. Ross, and S.L. Teitelbaum. TNF-alpha induces osteoclastogenesis by direct stimulation of macrophages exposed to permissive levels of RANK ligand. J. Clin. Invest. 2000; 106:14811488

29. Kurokouchi, K, Kambe, F, Yasukawa K, Izumi R, IshiguroN, Iwata, $\mathrm{H}$ and Seo, H. TNF-alpha increases expression of IL-6 and ICAM-1 genes through activation of NFkappab in osteoblast-like ROS17/2.8 cells. Journal of Bone and Mineral Research 1998; 13: 1290-1299. 